Supplement of Hydrol. Earth Syst. Sci., 24, 381-396, 2020

https://doi.org/10.5194/hess-24-381-2020-supplement

(c) Author(s) 2020. This work is distributed under

the Creative Commons Attribution 4.0 License.

(c) (1)

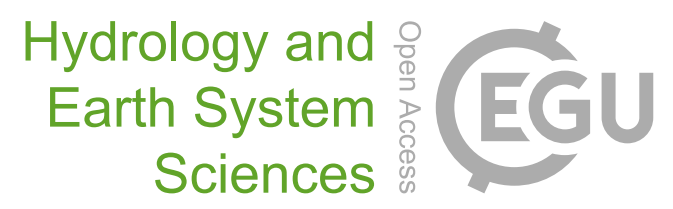

Supplement of

\title{
Inter-annual variability of the global terrestrial water cycle
}

Dongqin Yin and Michael L. Roderick

Correspondence to: Dongqin Yin (dongqin.yin@anu.edu.au,dongqin.yin@cau.edu.cn)

The copyright of individual parts of the supplement might differ from the CC BY 4.0 License. 
(a) $\overline{E_{0}} / \bar{P}$

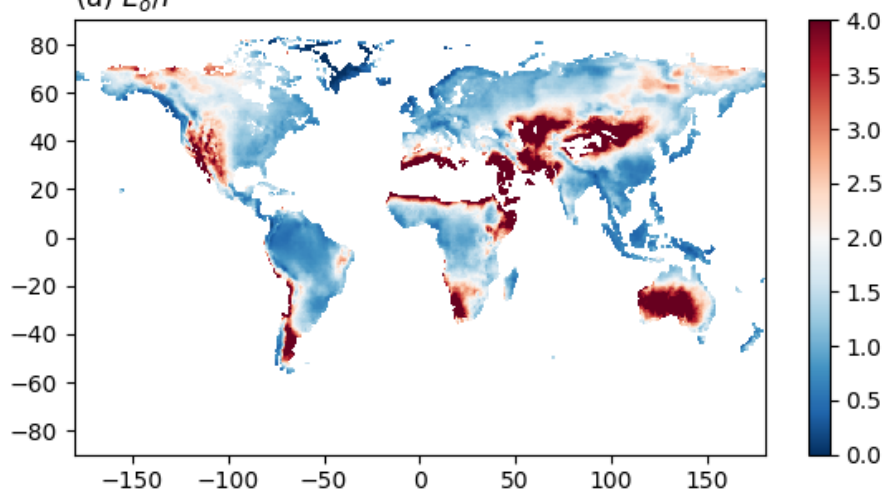

(b) $S_{\max }$

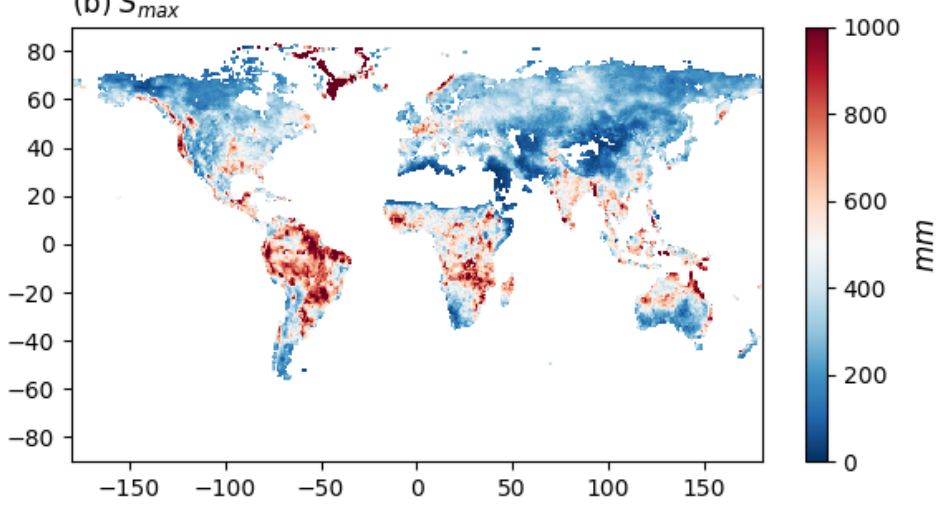

(c) $\overline{T_{a}}$

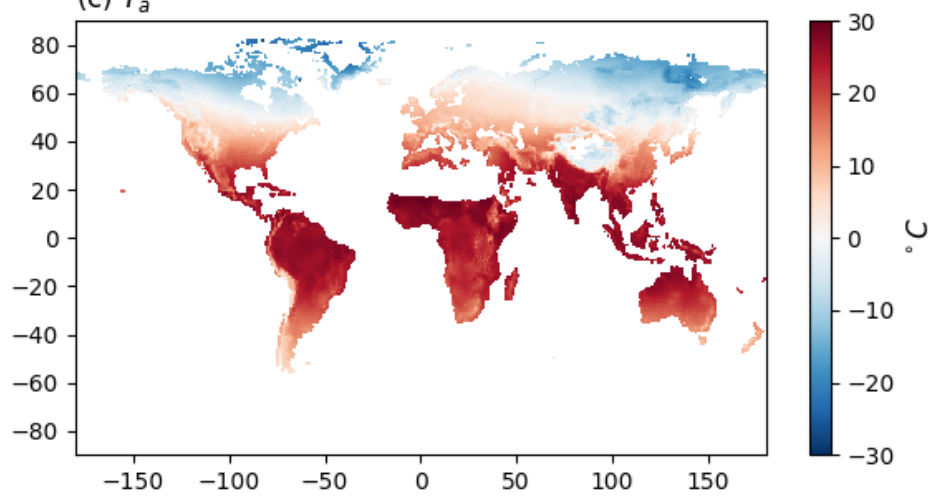

Figure S1. (a) Aridity index $\left(\overline{E_{\mathrm{o}}} / \bar{P}\right)$, (b) water storage capacity $\left(S_{\max }\right)$ and (c) mean annual air temperature $\left(\overline{T_{a}}\right)$ used in the analysis. 


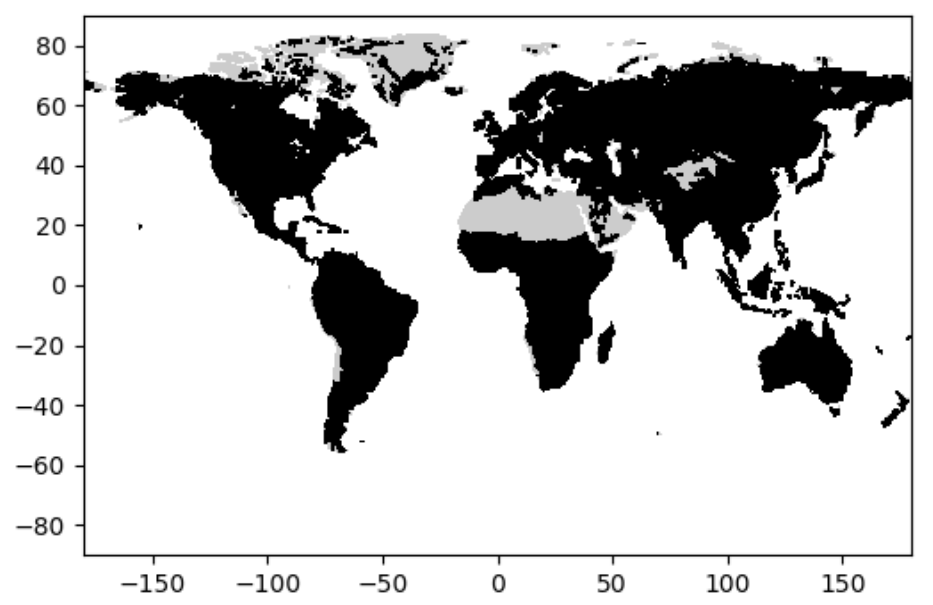

Figure S2. Spatial mask used in this study. Grey areas (e.g., Himalayan region, Sahara Desert, Greenland) have been masked out of the CDR database. 


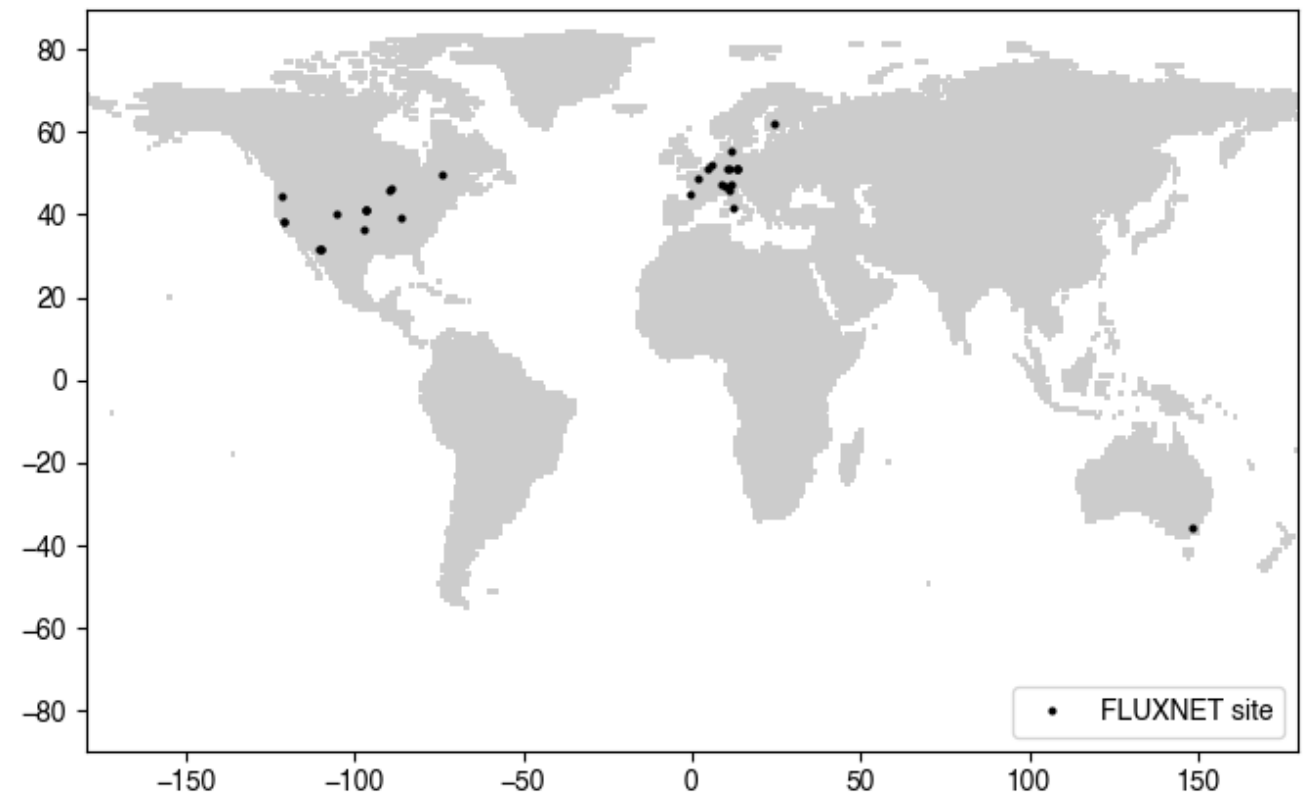

Figure S3. Location of the 32 FLUXNET sites used to evaluate the Climate Data Record (CDR). 
1.:

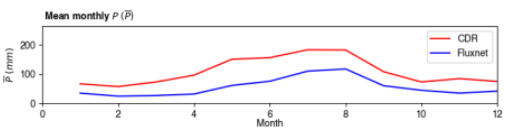

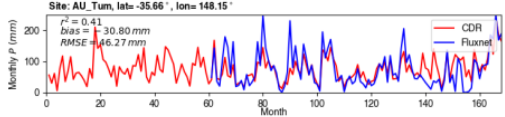

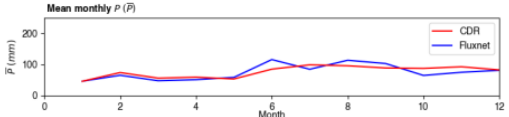

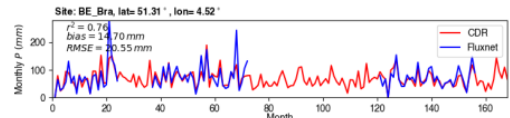

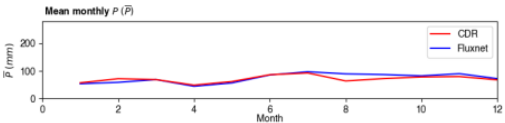

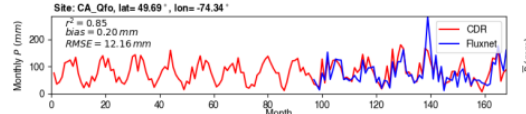

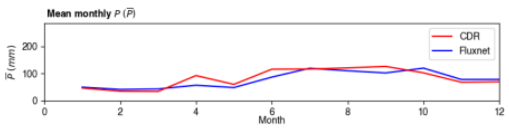

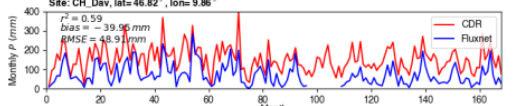

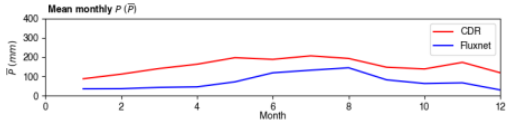

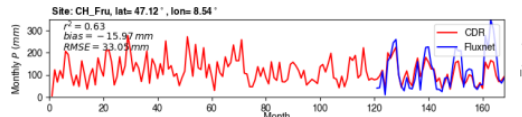

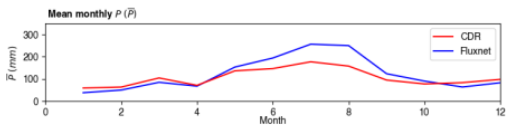

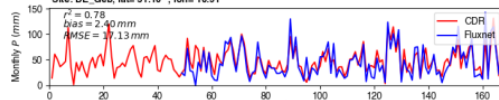

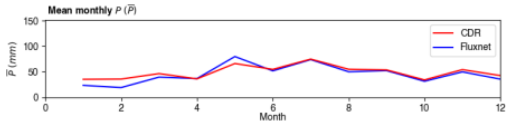

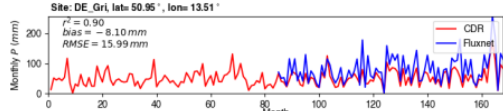

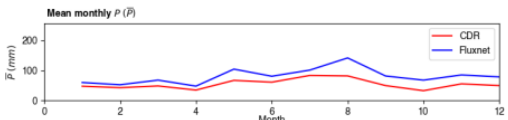

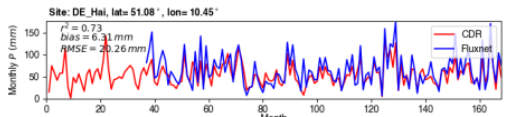

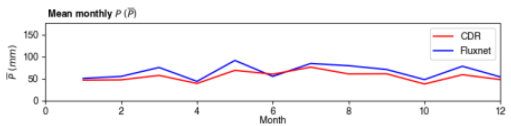

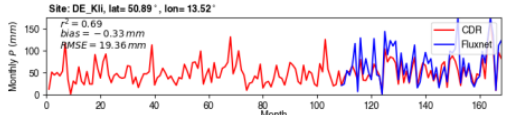

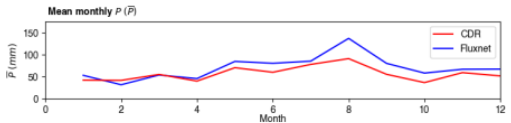

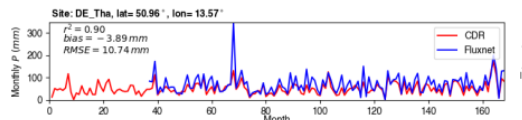

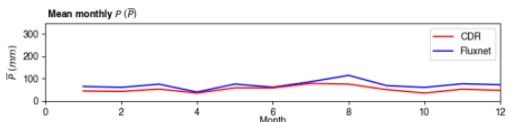

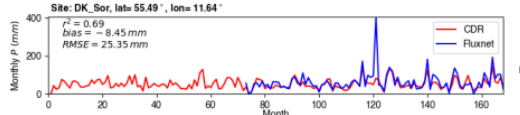

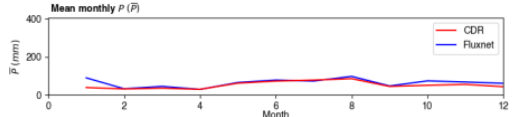

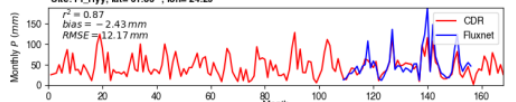

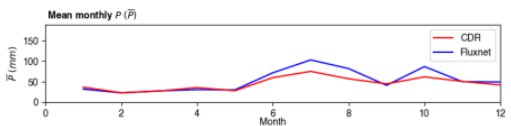

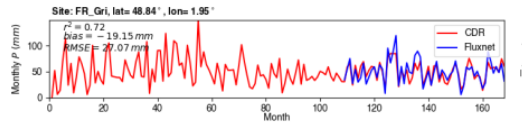

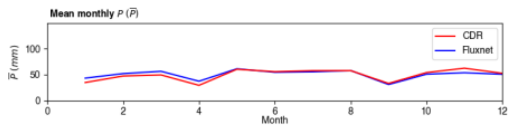

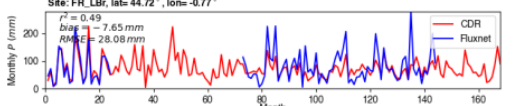

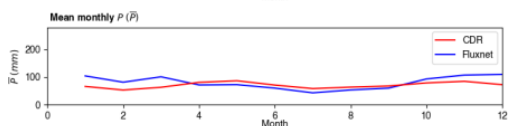

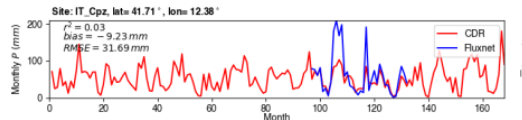

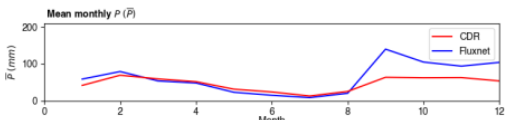

Figure S4. Comparison of monthly precipitation $\boldsymbol{P}$ time series (left panels) and mean monthly $\boldsymbol{P}$ (right panels)

between FLUXNET observations at 32 sites (Table S1) and the Climate Data Record (CDR). 
1.Find

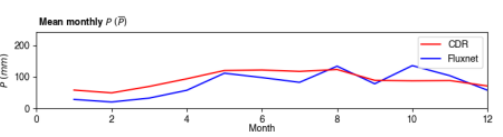

Ind

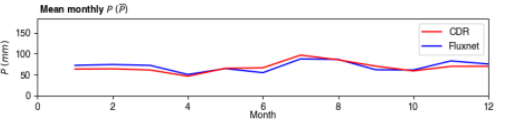

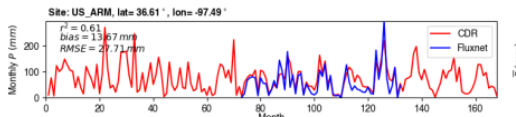

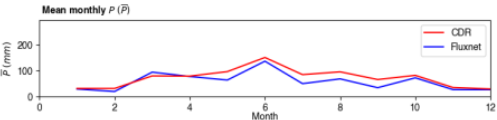

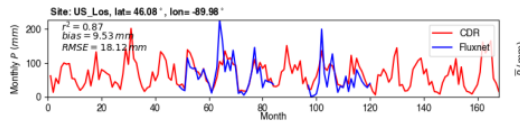

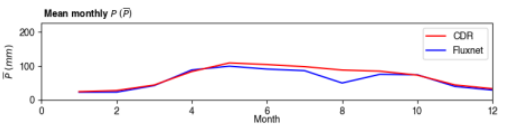

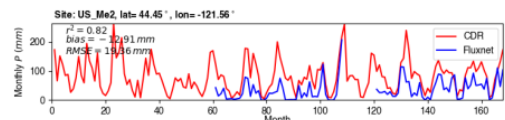

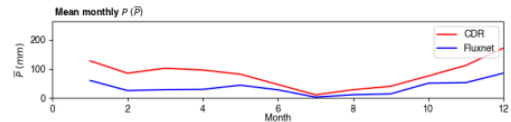

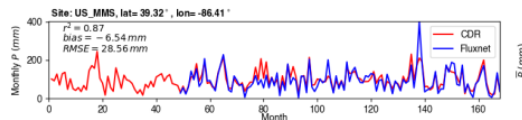

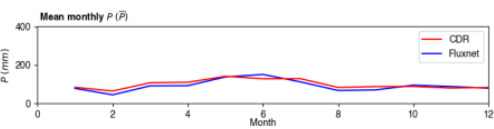

1.Mm

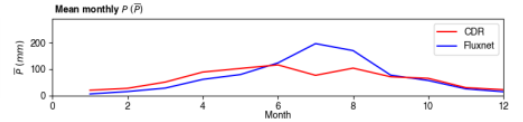

1.) Ww whw

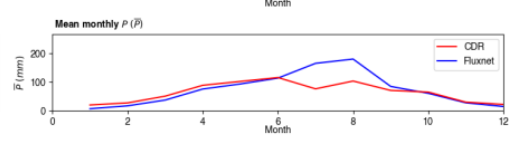

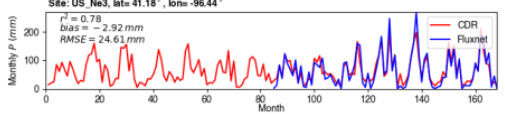

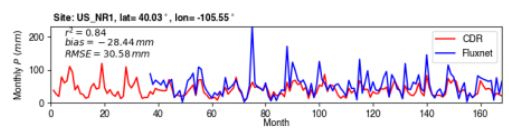

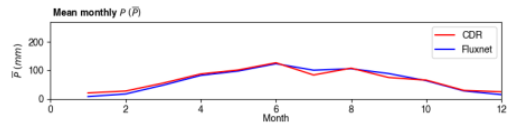

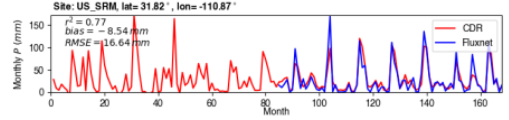

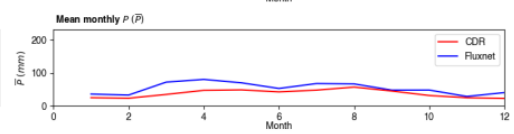

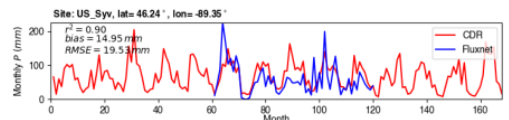

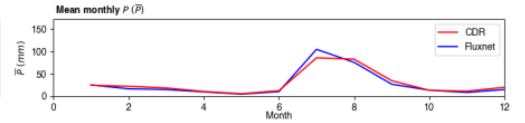

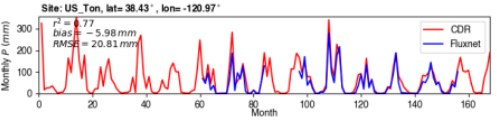

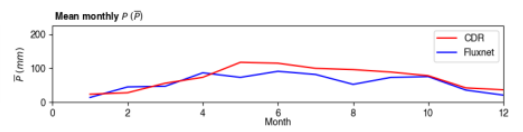

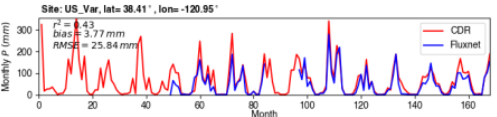

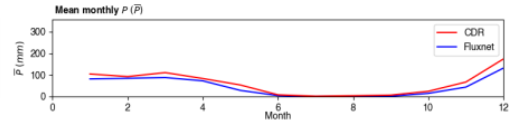

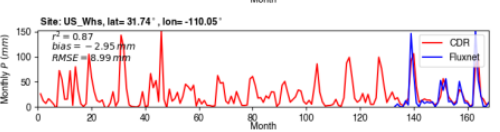

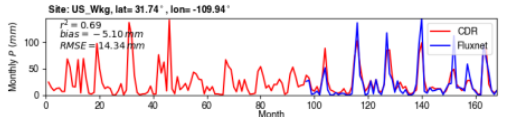

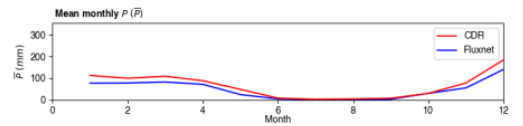

Figure $\mathbf{S 4}$ continued.
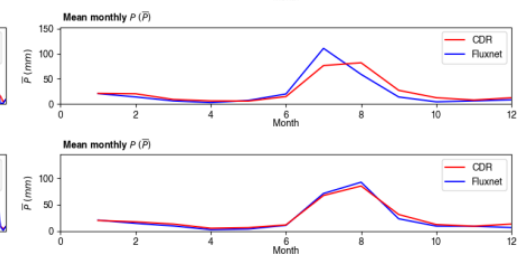

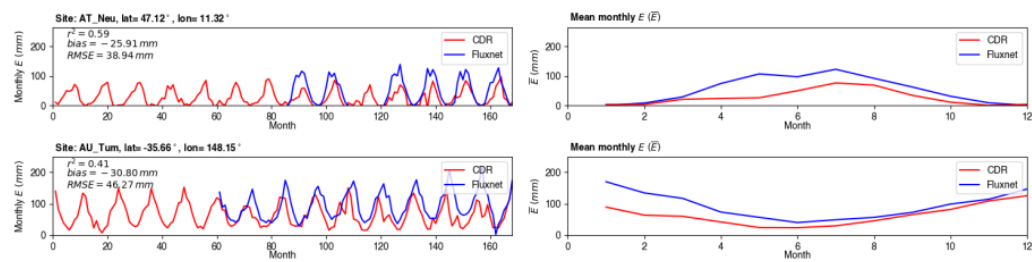

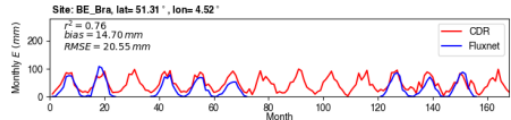

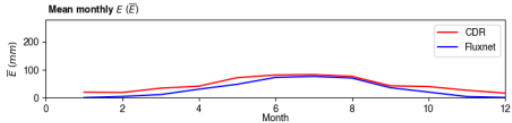

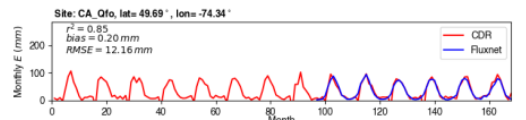

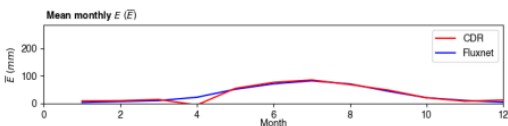

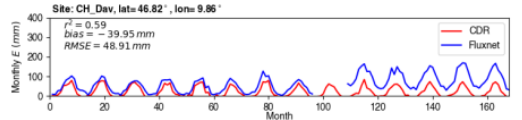

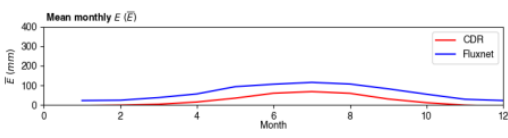

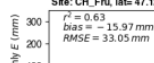

$=0_{\infty}$

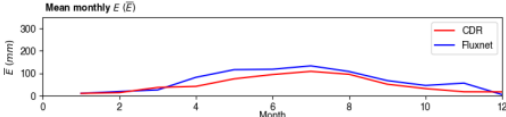

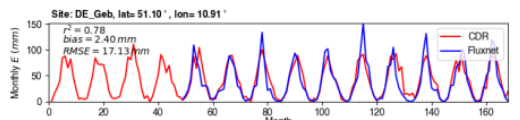

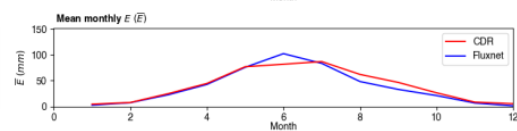

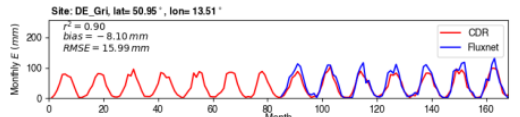

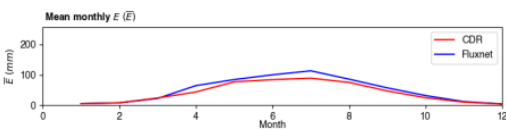

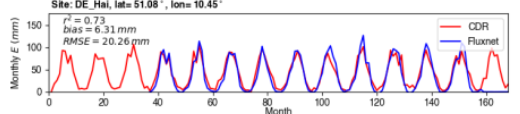

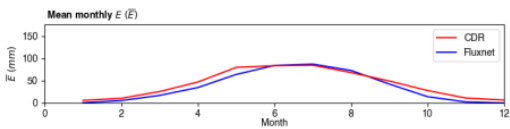

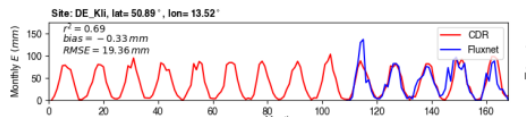

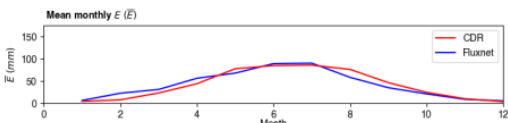

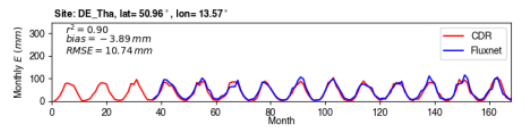

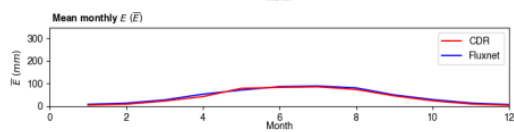

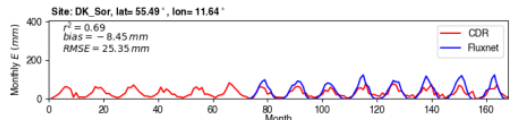

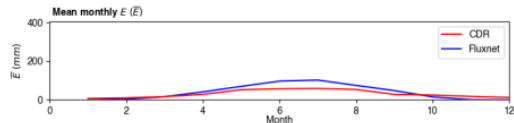

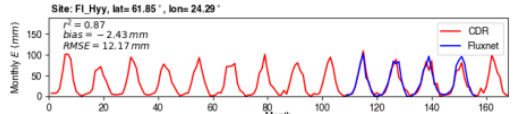

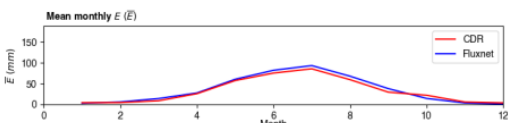

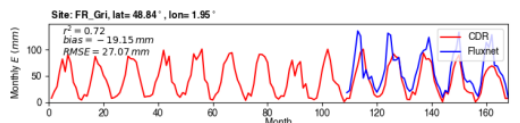

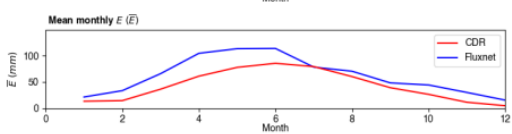

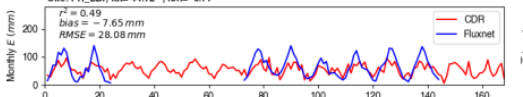

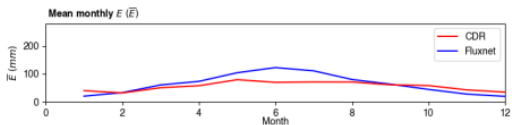

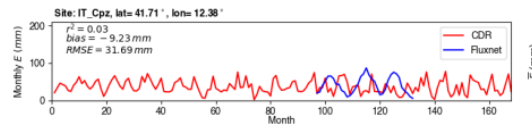

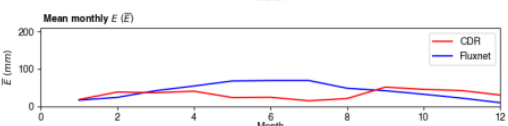

Figure S5. Comparison of monthly evapotranspiration $E$ time series (left panels) and mean monthly $E$ (right panels)

between FLUXNET site observations and the Climate Data Record (CDR). 


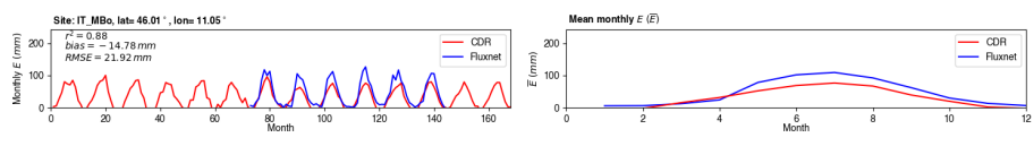

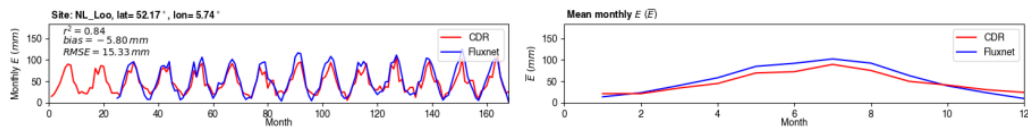

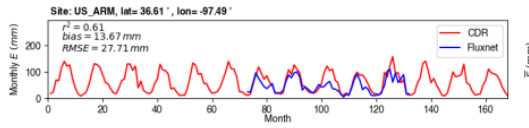

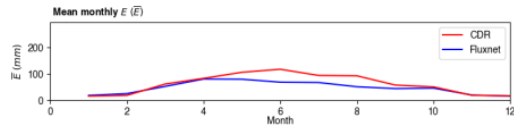
Numpu=

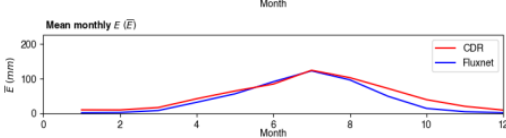

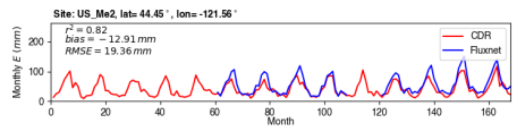

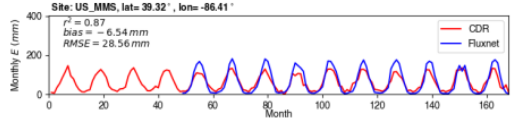

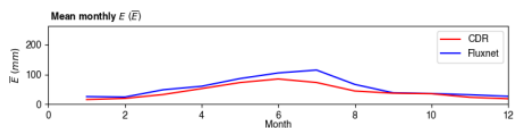
Huxpupviñ

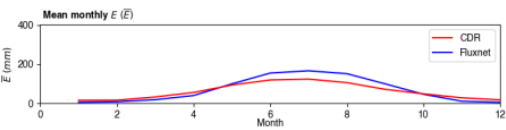

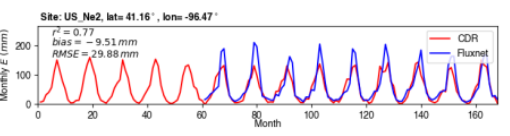

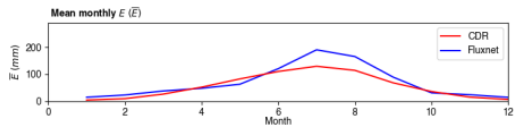
Ste

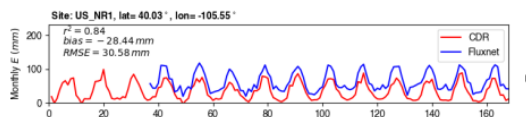

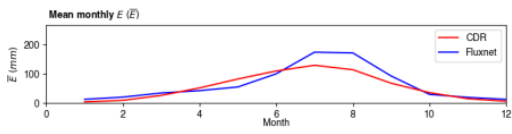

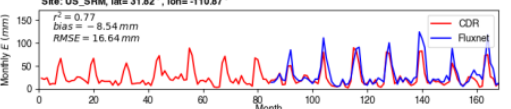

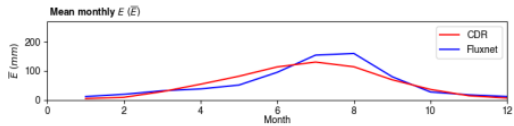

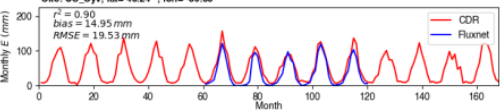

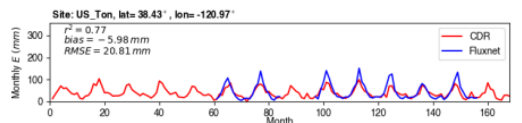
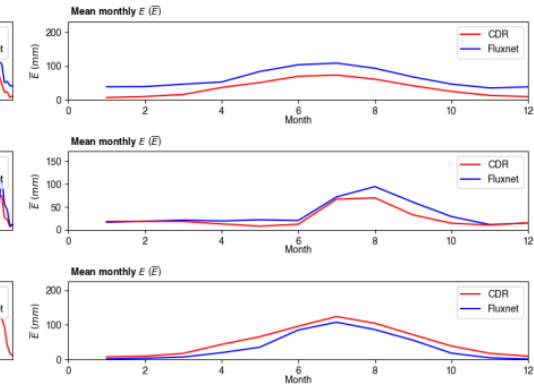

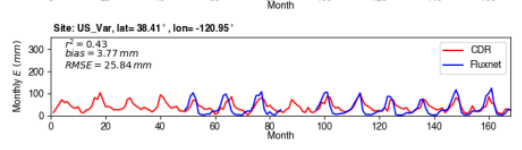
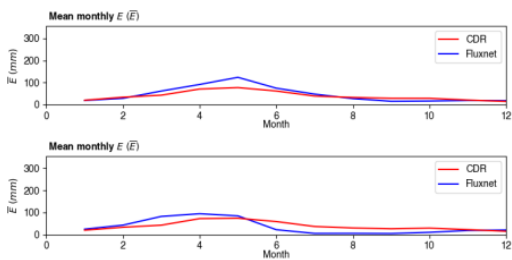

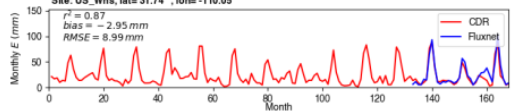

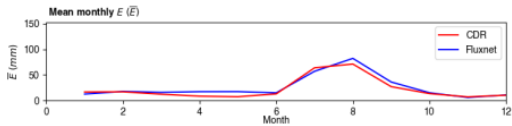

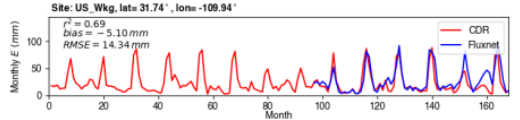

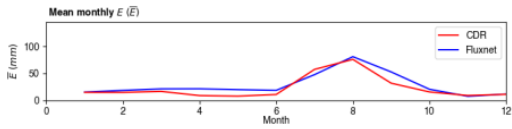

Figure S5 continued. 


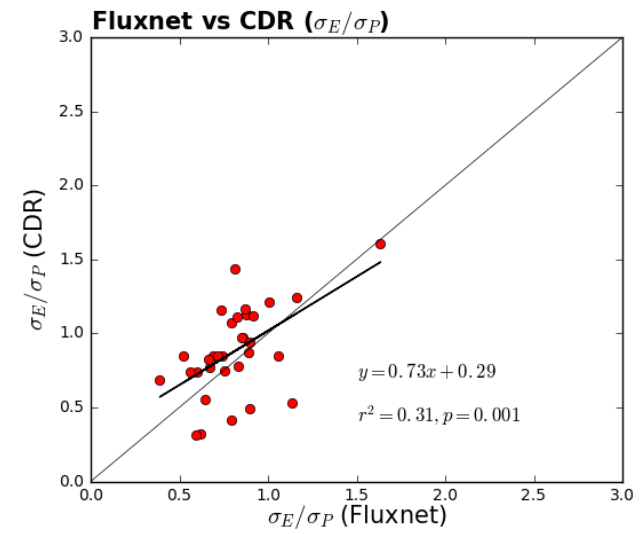

Figure S6. Comparison of ratio of standard deviation of monthly evapotranspiration $E$ to precipitation $P\left(\sigma_{E} / \sigma_{\mathrm{P}}\right)$ between FLUXNET site observations and the Climate Data Record (CDR). 

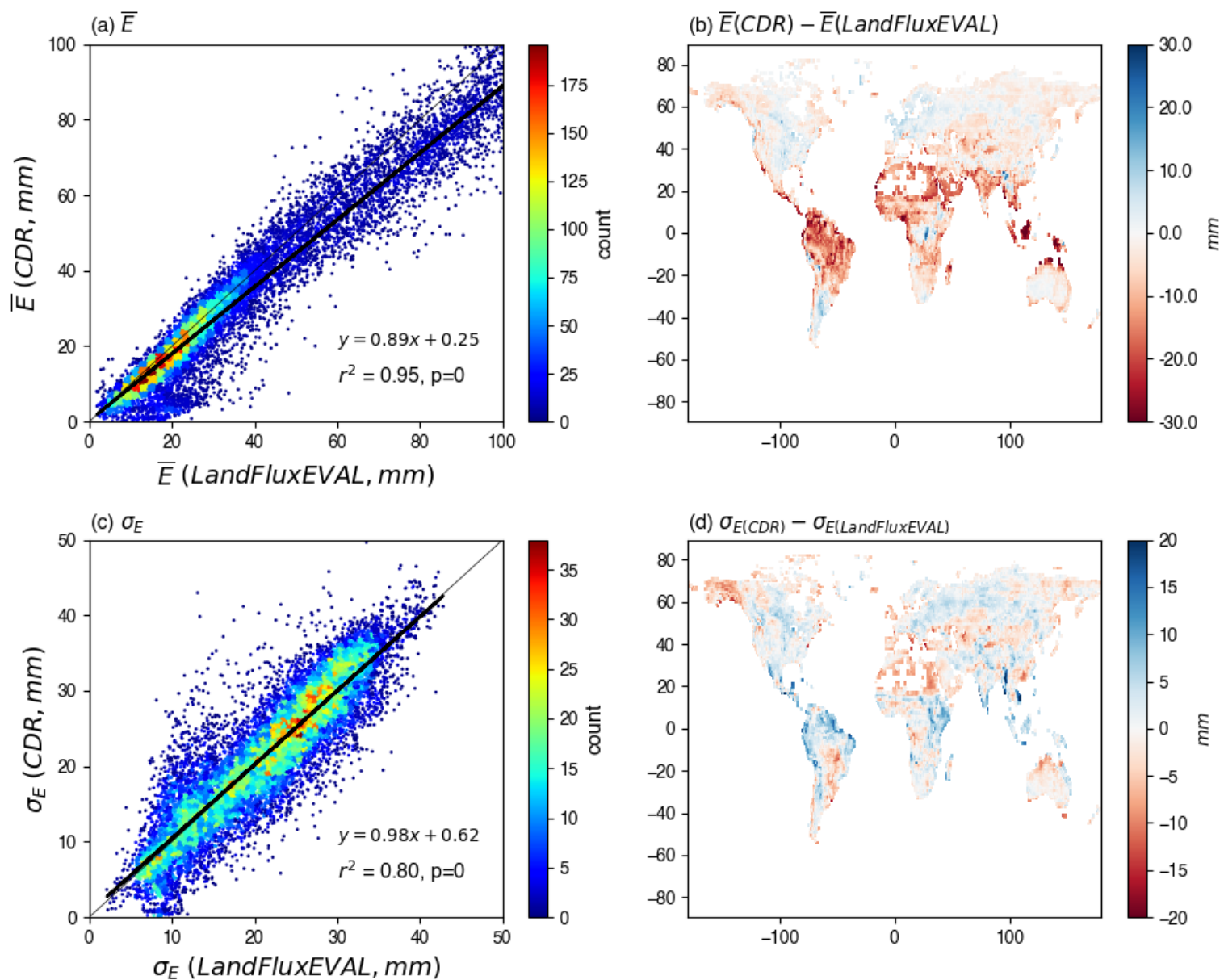

Figure S7. Comparison of monthly evapotranspiration $E$ between LandFluxEVAL and Climate Data Record (CDR) databases. Top panels (a) (b) show comparison of the mean monthly $(\bar{E})$ while bottom panels (c) (d) show comparison of the standard deviation $\left(\sigma_{E}\right)$ of monthly $E$. 

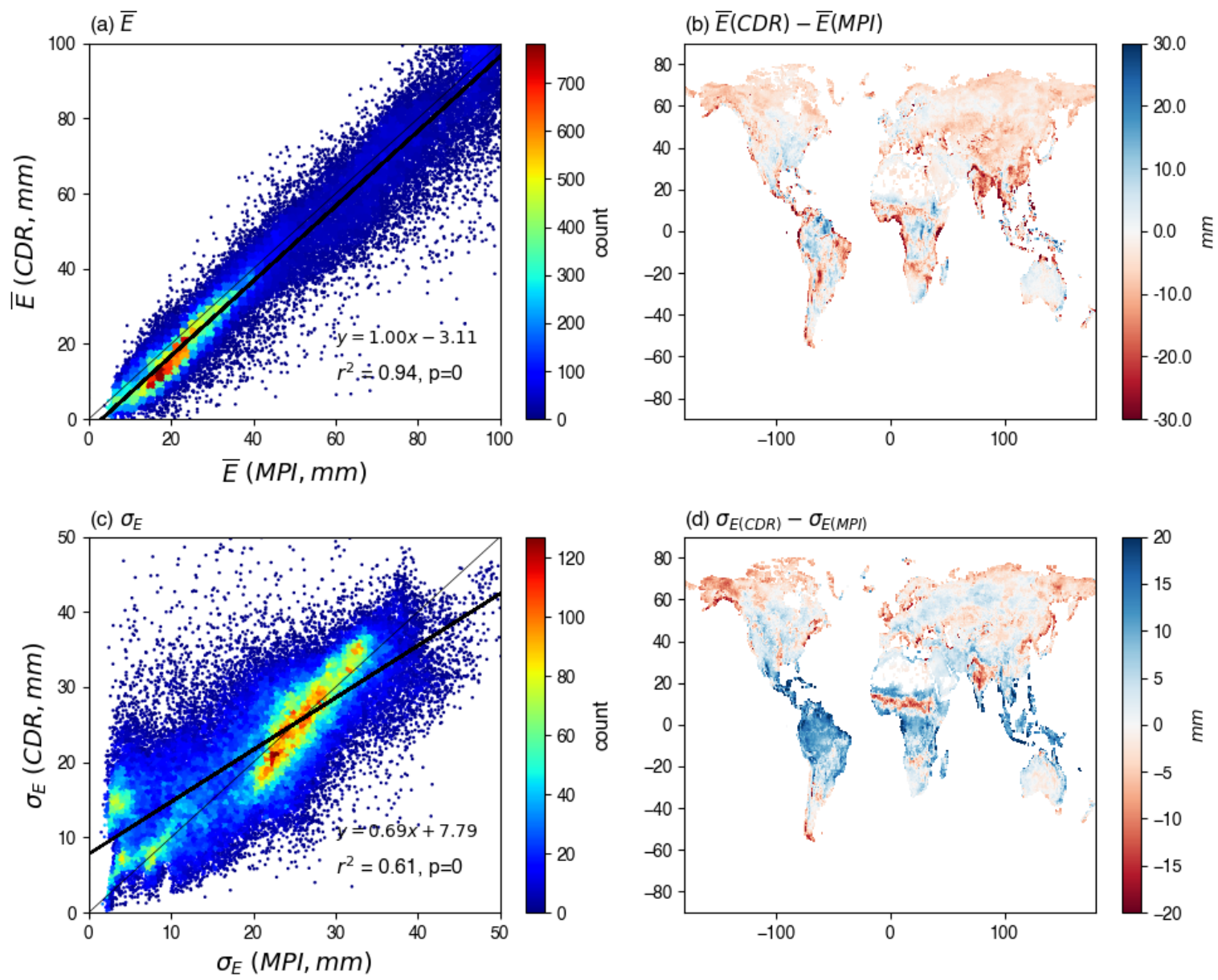

Figure S8. Comparison of monthly evapotranspiration $E$ between Max Planck Institute (MPI) and Climate Data Record (CDR) databases. Top panels (a) (b) show comparison of the mean monthly $(\bar{E})$ while bottom panels (c) (d) show comparison of the standard deviation $\left(\sigma_{E}\right)$ of monthly $E$. 

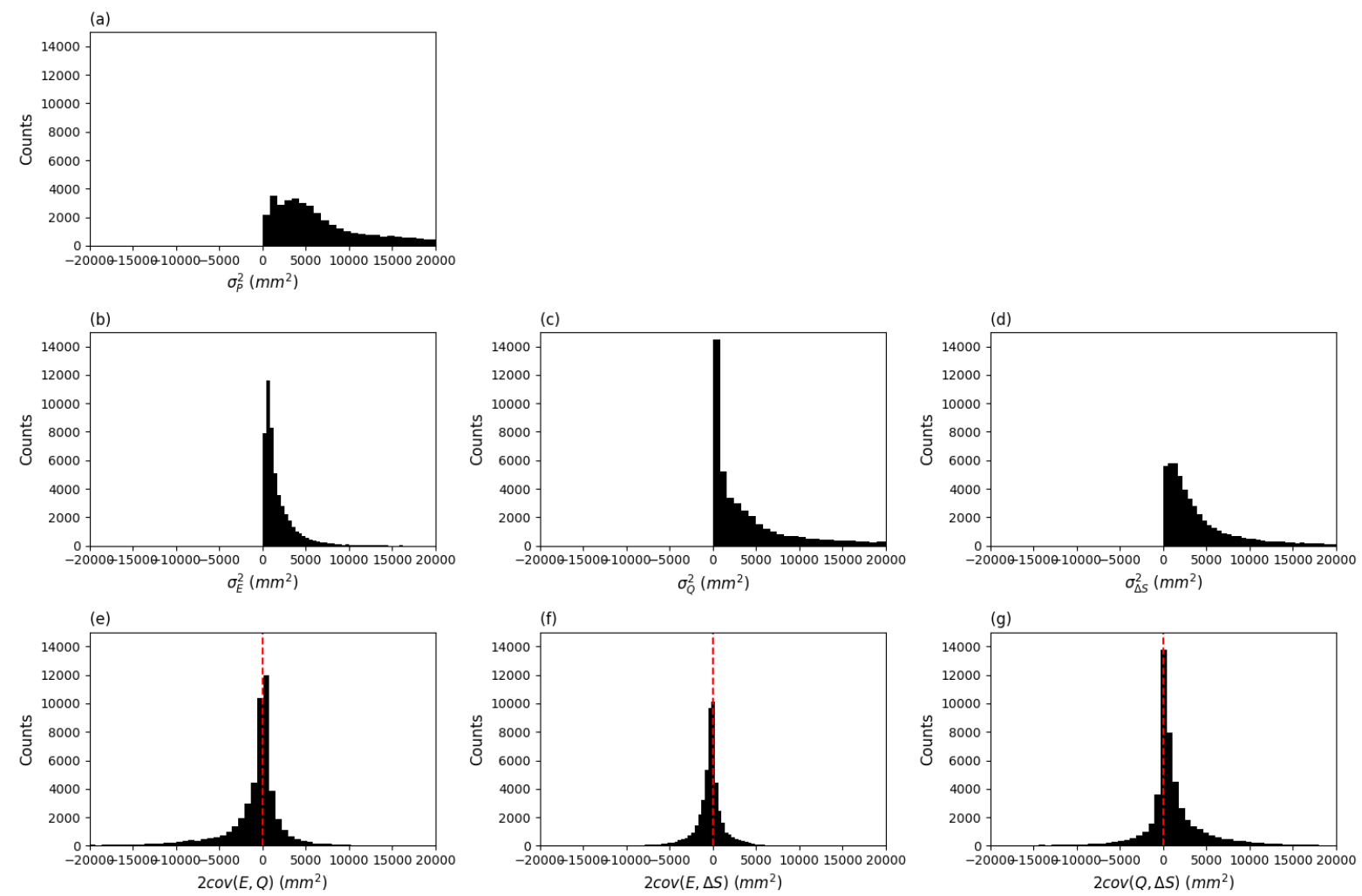

Figure S9. Distribution for each of the water cycle variances $\left(\sigma_{P}^{2}, \sigma_{E}^{2}, \sigma_{Q}^{2}, \sigma_{\Delta S}^{2}\right)$ and $\operatorname{covariances}(\operatorname{cov}(E, Q), \operatorname{cov}(E, \Delta S)$, $\operatorname{cov}(Q, \Delta S))$ shown in Fig. 3. Note that we have multiplied the covariances by two (see Eq. 2). 

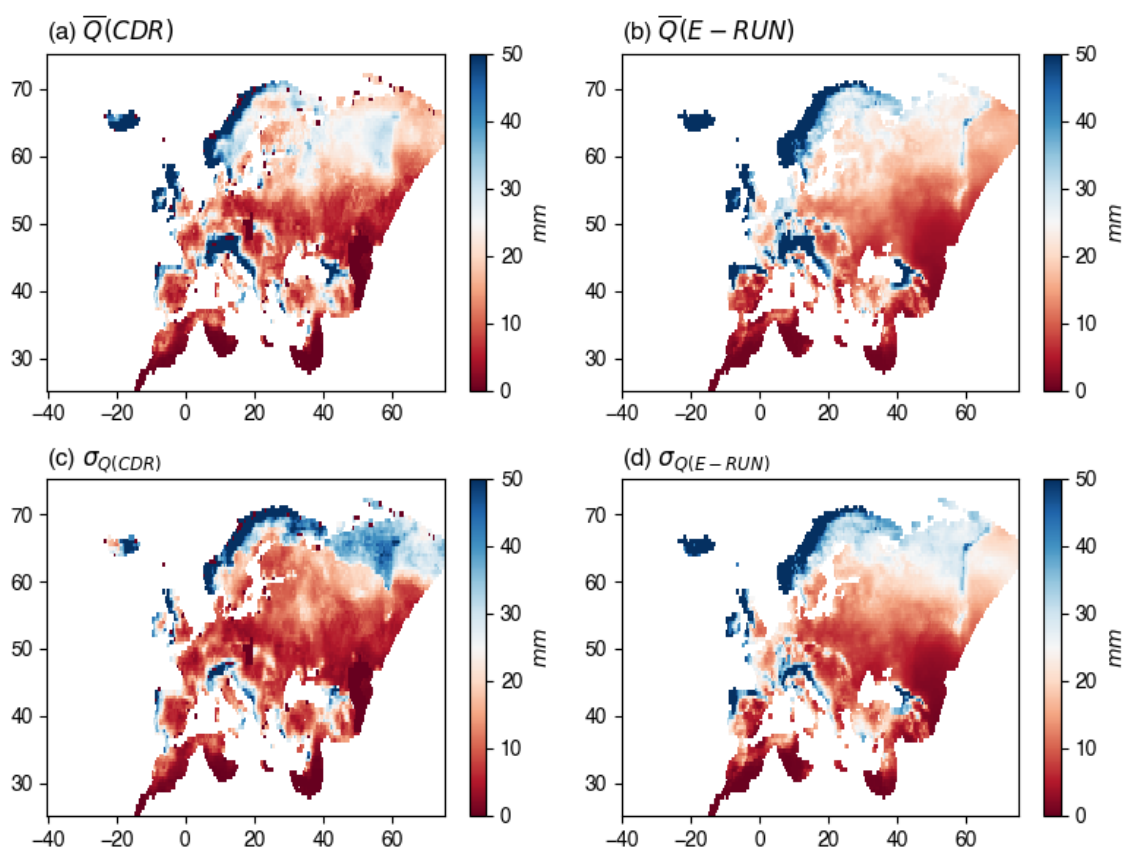

Figure S10. Mean $(\bar{Q})$ and standard deviation $\left(\sigma_{Q}\right)$ of monthly runoff $Q$ in the E-RUNOFF and Climate Data Record (CDR) databases in the area of spatial overlap (Europe). Top panels (a) (b) show the mean monthly $(\bar{Q})$ while bottom panels (c) (d) show the standard deviation $\left(\sigma_{Q}\right)$ of monthly $Q$. 

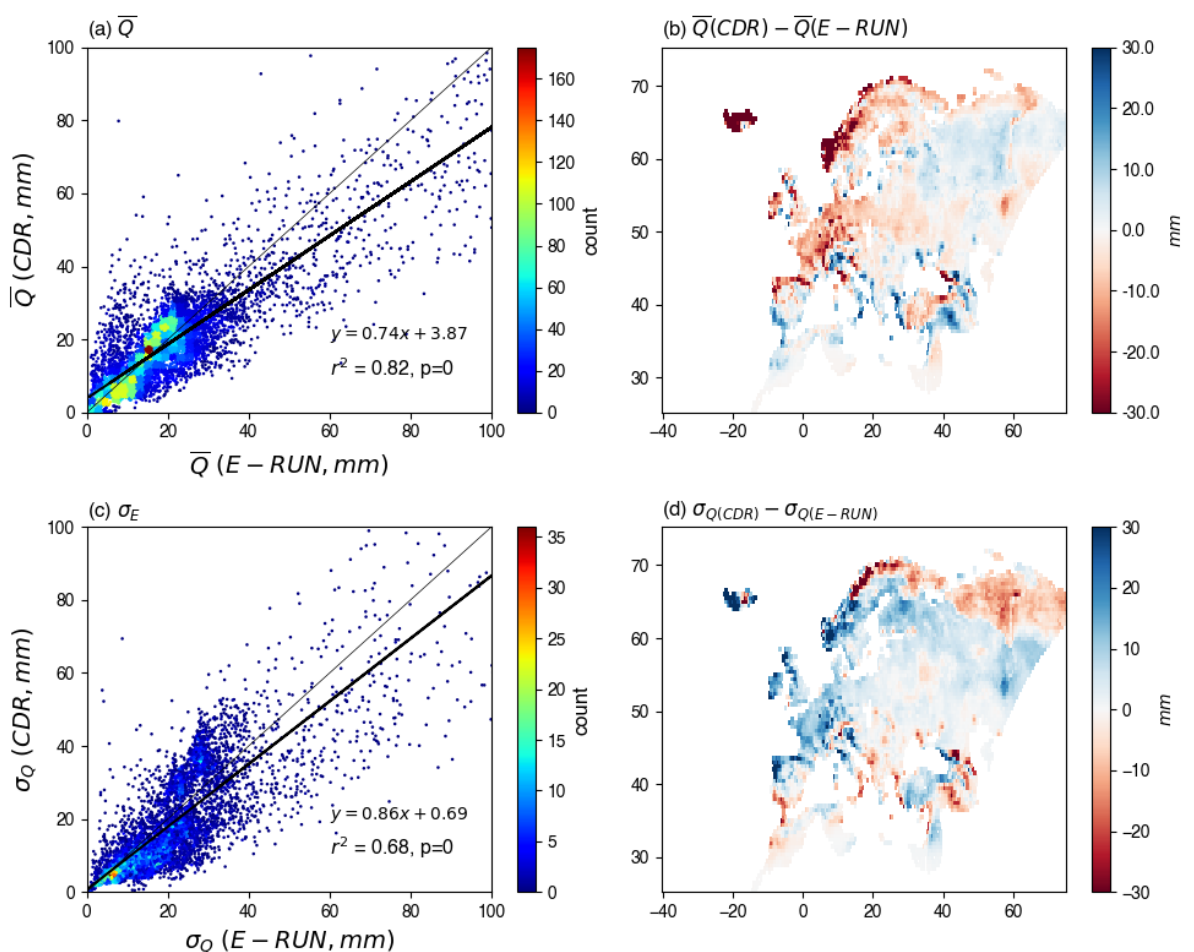

Figure S11. Comparison of monthly runoff $Q$ between the E-RUNOFF and Climate Data Record (CDR) databases in the area of spatial overlap (Europe). Top panels (a) (b) show comparison of the mean monthly $(\bar{Q})$ while bottom panels (c) (d) show comparison of the standard deviation $\left(\sigma_{Q}\right)$ of monthly $Q$. 

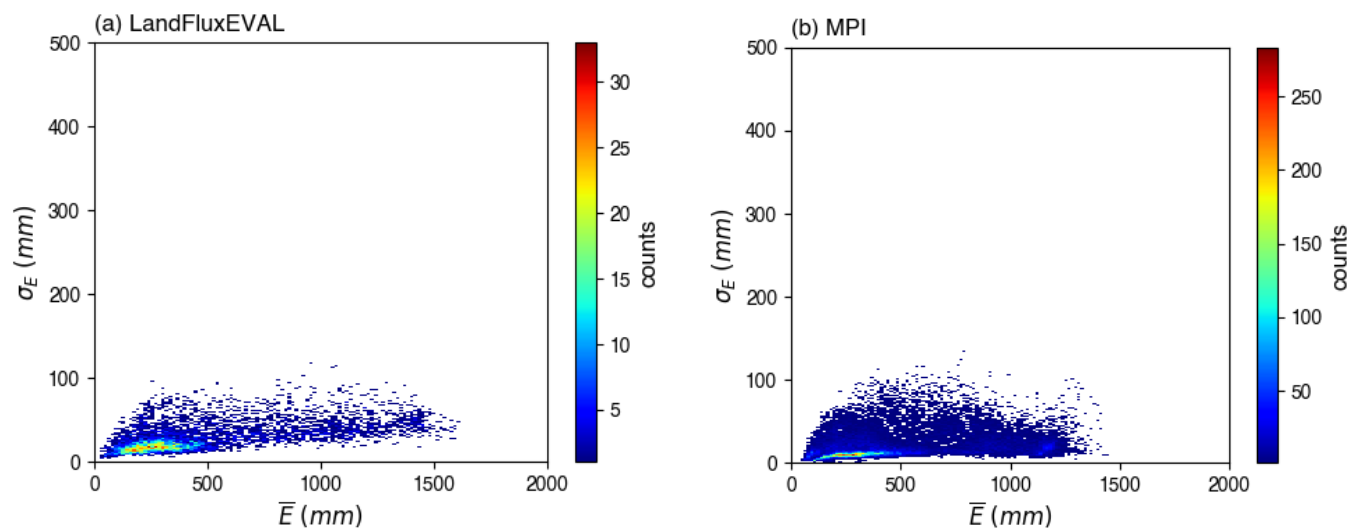

Figure S12. The same as Fig. 4b in main text but using evapotranspiration $E$ data from the (a) LandFluxEVAL and (b) MPI databases. 

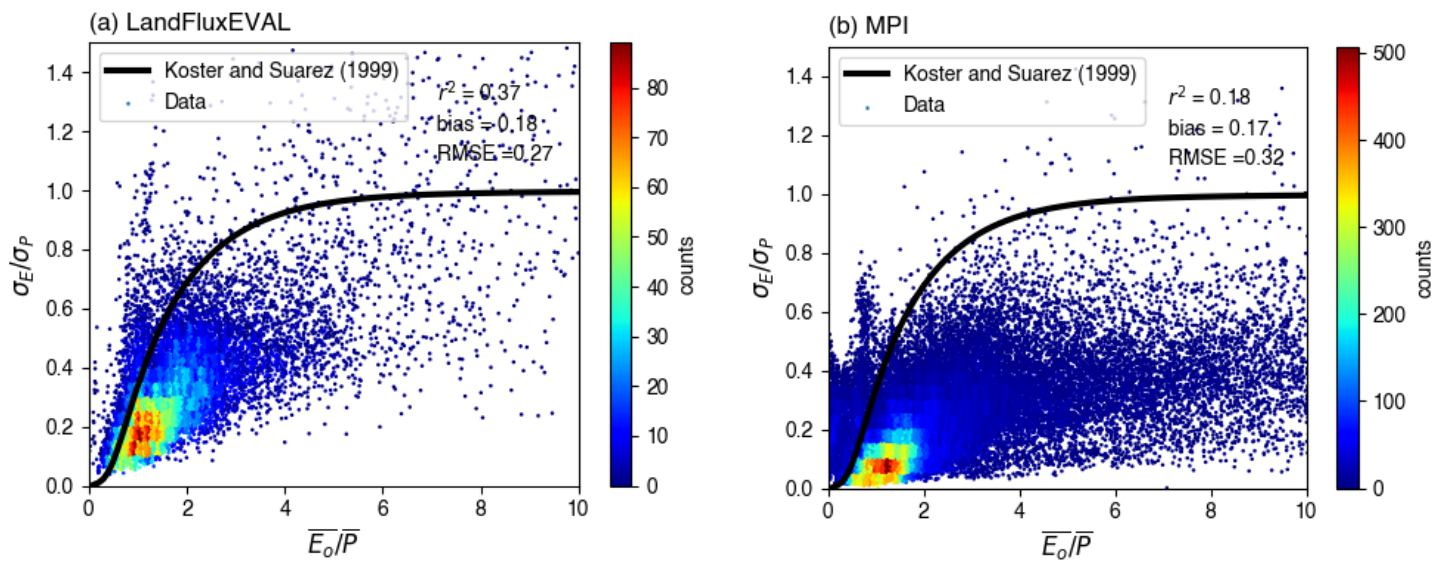

Figure S13. The same as Fig. 5a in main text but using evapotranspiration $E$ data from the (a) LandFluxEVAL and (b) MPI databases. 

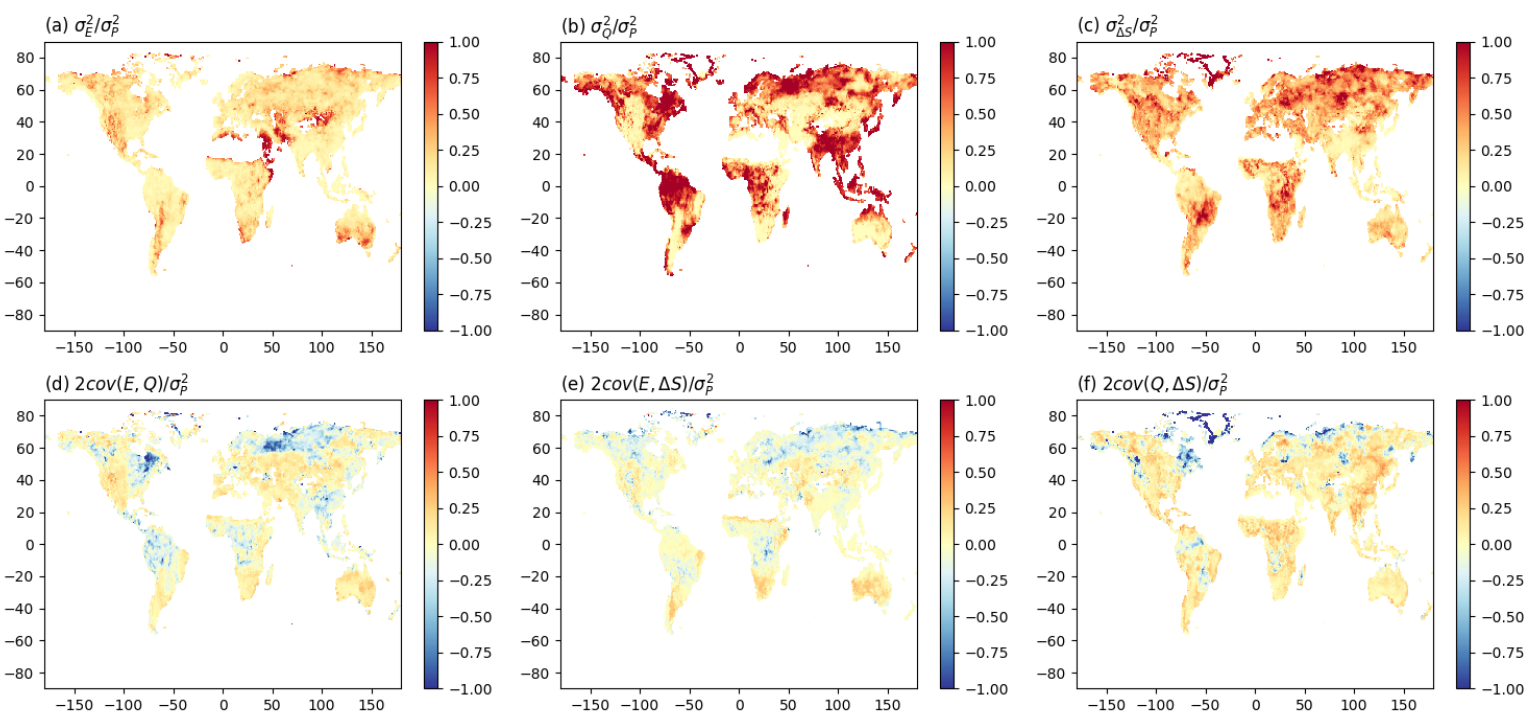

Figure S14. Inter-annual water cycle variances $\left(\sigma_{E}^{2}, \sigma_{Q}^{2}, \sigma_{\Delta S}^{2}\right)$ and $\operatorname{covariances}(\operatorname{cov}(E, Q), \operatorname{cov}(E, \Delta S), \operatorname{cov}(Q, \Delta S))$ expressed as a fraction of the variance of $P\left(\sigma_{P}^{2}\right)$. Note that we have multiplied the covariances by two (see Eq. 2). 
Table S1. Summary of comparisons of monthly precipitation $P$ and evapotranspiration $E$ between observations at 32 FLUXNET sites and the CDR database.

\begin{tabular}{|c|c|c|c|c|c|c|c|c|c|c|c|}
\hline Site ID & Site Name & Lat & Lon & Ref & Data period & $\begin{array}{l}r^{2} \\
(P)\end{array}$ & $\begin{array}{c}\text { bias } \\
(P, \mathbf{m m})\end{array}$ & $\begin{array}{c}\text { RMSE } \\
(P, \mathbf{m m})\end{array}$ & $\begin{array}{l}r^{2} \\
(E)\end{array}$ & $\begin{array}{c}\text { bias } \\
(E, \mathbf{m m})\end{array}$ & $\begin{array}{c}\text { RMSE } \\
(E, \mathbf{m m})\end{array}$ \\
\hline AT_Neu & Neustift & 47.1167 & 11.3175 & Wohlfahrt et al., 2008 & $2004-2005,2007-2010$ & 0.64 & 53.54 & 61.53 & 0.59 & -25.91 & 38.94 \\
\hline AU_Tum & Tumbarumba & -35.6566 & 148.1517 & Leuning et al., 2005 & $2002-2010$ & 0.56 & 1.08 & 39.34 & 0.41 & -30.80 & 46.27 \\
\hline BE_Bra & Brasschaat & 51.3076 & 4.5198 & Carrara et al., 2004 & $\begin{array}{c}1997-1998,2000-2002 \\
2007-2009\end{array}$ & 0.64 & -3.05 & 26.66 & 0.76 & 14.70 & 20.55 \\
\hline CA_Qfo & $\begin{array}{c}\text { Quebec - Eastern } \\
\text { Boreal, Mature } \\
\text { Black Spruce }\end{array}$ & 49.6925 & -74.3421 & Bergeron et al., 2006 & $2005-2010$ & 0.57 & 4.43 & 31.77 & 0.85 & 0.20 & 12.16 \\
\hline CH_Dav & Davos & 46.8153 & 9.8559 & Zielis et al., 2014 & $\begin{array}{l}1997-2004 \\
2006-2010\end{array}$ & 0.64 & 82.53 & 91.39 & 0.59 & -39.95 & 48.91 \\
\hline CH_Fru & Früebüel & 47.1158 & 8.5378 & Imer et al., 2013 & $2007-2010$ & 0.65 & -15.42 & 55.86 & 0.63 & -15.97 & 33.05 \\
\hline DE_Geb & Gebesee & 51.1001 & 10.9143 & Anthoni et al., 2004 & $2001-2010$ & 0.69 & 3.78 & 17.69 & 0.78 & 2.40 & 17.13 \\
\hline DE_Gri & Grillenburg & 50.9500 & 13.5126 & Prescher et al., 2010 & $2004-2010$ & 0.70 & -26.32 & 37.67 & 0.90 & -8.10 & 15.99 \\
\hline DE_Hai & Hainich & 51.0792 & 10.4530 & Knohl et al., 2003 & $2000-2012$ & 0.70 & -10.35 & 23.17 & 0.73 & 6.31 & 20.26 \\
\hline DE_Kli & Klingenberg & 50.8931 & 13.5224 & Prescher et al., 2010 & $2006-2010$ & 0.68 & -13.61 & 28.05 & 0.69 & -0.33 & 19.36 \\
\hline DE_Tha & Tharandt & 50.9624 & 13.5652 & $\begin{array}{c}\text { Grünwald and Bernhofer, } \\
2007\end{array}$ & $2000-2010$ & 0.66 & -18.71 & 32.35 & 0.90 & -3.89 & 10.74 \\
\hline DK_Sor & Soroe & 55.4859 & 11.6446 & Pilegaard et al., 2011 & $2003-2010$ & 0.45 & -11.07 & 39.31 & 0.69 & -8.45 & 25.35 \\
\hline FI_Hyy & Hyytiala & 61.8474 & 24.2948 & Suni et al., 2003 & $2006-2009$ & 0.78 & -7.07 & 20.43 & 0.87 & -2.43 & 12.17 \\
\hline FR_Gri & Grignon & 48.8442 & 1.9519 & Loubet et al., 2011 & $2006-2010$ & 0.69 & -0.81 & 12.35 & 0.72 & -19.15 & 27.07 \\
\hline FR_LBr & Le Bray & 44.7171 & -0.7693 & Berbigier et al., 2001 & $\begin{array}{l}1997-1998 \\
2003-2008\end{array}$ & 0.56 & -9.19 & 39.93 & 0.49 & -7.65 & 28.08 \\
\hline IT_Cpz & Castelporziano & 41.7053 & 12.3761 & Garbulsky et al., 2008 & $2005-2007$ & 0.76 & -15.90 & 40.42 & 0.03 & -9.23 & 31.69 \\
\hline
\end{tabular}




\begin{tabular}{|c|c|c|c|c|c|c|c|c|c|c|c|}
\hline IT_MBo & Monte Bondone & 46.0147 & 11.0458 & Marcolla et al., 2011 & $2003-2008$ & 0.36 & 12.43 & 48.14 & 0.88 & -14.78 & 21.92 \\
\hline NL_Loo & Loobos & 52.1666 & 5.7436 & Moors 2012 & $1999-2010$ & 0.56 & -2.16 & 24.78 & 0.84 & -5.80 & 15.33 \\
\hline US_ARM & $\begin{array}{c}\text { ARM Southern } \\
\text { Great Plains site- } \\
\text { Lamont }\end{array}$ & 36.6058 & -97.4888 & $\begin{array}{l}\text { Baldocchi and Sturtevant } \\
2015\end{array}$ & $2003-2007$ & 0.71 & 13.53 & 31.78 & 0.61 & 13.67 & 27.71 \\
\hline US_Los & Lost Creek & 46.0827 & -89.9792 & Baker et al., 2003 & $\begin{array}{l}2001-2003 \\
2005-2006\end{array}$ & 0.52 & 7.76 & 32.82 & 0.87 & 9.53 & 18.12 \\
\hline US_Me2 & $\begin{array}{l}\text { Metolius mature } \\
\text { ponderosa pine }\end{array}$ & 44.4523 & -121.5574 & Law (2002-2014) & $\begin{array}{l}2002-2005 \\
2007-2010\end{array}$ & 0.54 & 45.31 & 56.84 & 0.82 & -12.91 & 19.36 \\
\hline US_MMS & $\begin{array}{l}\text { Morgan Monroe } \\
\text { State Forest }\end{array}$ & 39.3232 & -86.4131 & $\begin{array}{l}\text { Novick and Phillips } \\
\quad(1999-2014)\end{array}$ & $2001-2010$ & 0.72 & 6.60 & 31.44 & 0.87 & -6.54 & 28.56 \\
\hline US_Ne1 & $\begin{array}{l}\text { Mead - irrigated } \\
\text { continuous maize } \\
\text { site }\end{array}$ & 41.1651 & -96.4766 & Suyker (2001-2013a) & $2002-2010$ & 0.45 & -6.64 & 51.86 & 0.82 & -13.95 & 30.17 \\
\hline US_Ne2 & $\begin{array}{l}\text { Mead - irrigated } \\
\text { maize-soybean } \\
\text { rotation site }\end{array}$ & 41.1649 & -96.4701 & Suyker (2001-2013b) & $2002-2010$ & 0.56 & -8.77 & 46.45 & 0.77 & -9.51 & 29.88 \\
\hline US_Ne3 & $\begin{array}{l}\text { Mead - rainfed } \\
\text { maize-soybean } \\
\text { rotation site }\end{array}$ & 41.1797 & -96.4397 & Suyker (2001-2013c) & $2004-2010$ & 0.88 & 2.28 & 21.43 & 0.78 & -2.92 & 24.61 \\
\hline US_NR1 & $\begin{array}{l}\text { Niwot Ridge } \\
\text { Forest (LTER } \\
\text { NWT1) }\end{array}$ & 40.0329 & -105.5464 & Blanken (1998-2014) & $2000-2010$ & 0.51 & -16.06 & 29.57 & 0.84 & -28.44 & 30.58 \\
\hline US_SRM & $\begin{array}{l}\text { Santa Rita } \\
\text { Mesquite }\end{array}$ & 31.8214 & -110.8661 & $\begin{array}{l}\text { Barron-Gafford et al., } \\
2011\end{array}$ & $2004-2010$ & 0.81 & 1.34 & 15.40 & 0.77 & -8.54 & 16.64 \\
\hline US_Syv & $\begin{array}{c}\text { Sylvania } \\
\text { Wilderness Area }\end{array}$ & 46.2420 & -89.3477 & Desai et al., 2008 & $2002-2006$ & 0.33 & 13.17 & 40.68 & 0.90 & 14.95 & 19.53 \\
\hline US_Ton & Tonzi Ranch & 38.4316 & -120.9660 & Baldocchi et al., 2010 & $\begin{array}{l}2002-2003 \\
2005-2009\end{array}$ & 0.89 & 14.68 & 27.44 & 0.77 & -5.98 & 20.81 \\
\hline
\end{tabular}




\begin{tabular}{c|c|c|c|c|c|c|c|c|c|c|c}
\hline US_Var & Vaira Ranch- Ione & 38.4133 & -120.9507 & Baldocchi et al., 2004 & $\begin{array}{c}2001-2003, \\
2005-2010\end{array}$ & $\mathbf{0 . 8 6}$ & 16.91 & 30.92 & $\mathbf{0 . 4 3}$ & 3.77 & 25.84 \\
\hline US_Whs & $\begin{array}{c}\text { Walnut Gulch } \\
\text { Lucky Hills Shrub }\end{array}$ & 31.7438 & -110.0522 & Biederman et al., 2016 & $2008-2010$ & $\mathbf{0 . 6 5}$ & 1.89 & 21.26 & $\mathbf{0 . 8 7}$ & -2.95 & 8.99 \\
\hline US_Wkg & $\begin{array}{c}\text { Walnut Gulch } \\
\text { Kendall Grasslands }\end{array}$ & 31.7365 & -109.9419 & Biederman et al., 2016 & $2005-2010$ & $\mathbf{0 . 7 8}$ & 1.59 & 15.66 & $\mathbf{0 . 6 9}$ & $-\mathbf{- 5 . 1 0}$ & 14.34 \\
\hline
\end{tabular}

* Significant $r^{2}$ values (linear regression $p<0.05$ ) are shown in bold. 


\section{References}

Anthoni, P. M., and Coauthors, 2004: Forest and agricultural land-use-dependent CO2 exchange in Thuringia, Germany. Global Change Biology, 10, 2005-2019.

B., L., and Coauthors, 2011: Carbon, nitrogen and Greenhouse gases budgets over a four years crop rotation in northern France. Plant and Soil, 343, 109-137.

Baker, I., and Coauthors, 2003: Simulated And Observed Fluxes Of Sensible And Latent Heat And CO2 At The WLEF-TV Tower Using SiB2.5. Global Change Biology, 9, 1262-1277.

Baldocchi, D., and C. Sturtevant, 2015: Does day and night sampling reduce spurious correlation between canopy photosynthesis and ecosystem respiration ?. Agricultural and Forest Meteorology, 207, 117-126.

Baldocchi, D. D., L. Xu, and N. Kiang, 2004: How plant functional-type, weather, seasonal drought, and soil physical properties alter water and energy fluxes of an oak-grass savanna and an annual grassland.

Agricultural and Forest Meteorology, 123, 13-39.

Baldocchi, D. D., and Coauthors, 2010: On the differential advantages of evergreenness and deciduousness in mediterranean oak woodlands: a flux perspective. Ecological Applications, 20, 1583-1597.

Barron-Gafford, G. A., R. L. Scott, G. D. Jenerette, and T. E. Huxman, 2011: The relative controls of temperature, soil moisture, and plant functional group on soil $\mathrm{CO} 2$ efflux at diel, seasonal, and annual scales. Journal of Geophysical Research: Biogeosciences, 116.

Berbigier, P., J. M. Bonnefond, and P. Mellmann, 2001: CO2 and water vapour fluxes for 2 years above Euroflux forest site. Agricultural and Forest Meteorology, 108, 183-197.

Bergeron, O., H. A. Margolis, T. A. Black, C. Coursolle, A. L. Dunn, A. G. Barr, and S. C. Wofsy, 2006: Comparison of carbon dioxide fluxes over three boreal black spruce forests in Canada. Global Change Biology, 13, 89-107. Biederman, J. A., and Coauthors, 2016: Terrestrial carbon balance in a drier world: the effects of water availability in southwestern North America. Global Change Biology, 22, 1867-1879.

Blanken, P., 1998-2014: FLUXNET2015 US-NR1 Niwot Ridge Forest (LTER NWT1).

Carrara, A., I. A. Janssens, J. Curiel Yuste, and R. Ceulemans, 2004: Seasonal changes in photosynthesis, respiration and NEE of a mixed temperate forest. Agricultural and Forest Meteorology, 126, 15-31.

Desai, A. R., and Coauthors, 2008: Influence of vegetation and seasonal forcing on carbon dioxide fluxes across the Upper Midwest, USA: Implications for regional scaling. Agricultural and Forest Meteorology, 148, 288-308. Garbulsky, M. F., J. Penuelas, D. Papale, and I. Filella, 2008: Remote estimation of carbon dioxide uptake by a Mediterranean forest. Global Change Biology, 14, 2860-2867.

Grünwald, T., and C. Bernhofer, 2007: A decade of carbon, water and energy flux measurements of an old spruce forest at the Anchor Station Tharandt. Tellus B Chem. Phys. Meteorol., 59, 387-396.

Imer, D., L. Merbold, W. Eugster, and N. Buchmann, 2013: Temporal and spatial variations of soil CO2, $\mathrm{CH} 4$ and $\mathrm{N} 2 \mathrm{O}$ fluxes at three differently managed grasslands. Biogeosciences, 10, 5931-5945.

Knohl, A., E. D. Schulze, O. Kolle, and N. Buchmann, 2003: Large carbon uptake by an unmanaged 250-year-old deciduous forest in Central Germany. Agricultural and Forest Meteorology, 118, 151-167.

Law, B., 2002-2014: FLUXNET2015 US-Me2 Metolius mature ponderosa pine.

Leuning, R., H. A. Cleugh, S. J. Zegelin, and D. Hughes, 2005: Carbon and water fluxes over a temperate Eucalyptus forest and a tropical wet/dry savanna in Australia: measurements and comparison with MODIS remote sensing estimates. Agricultural and Forest Meteorology, 129, 151-173.

Marcolla, B., and Coauthors, 2011: Climatic controls and ecosystem responses drive the inter-annual variability of the net ecosystem exchange of an alpine meadow. Agricultural and Forest Meteorology, 151, 1233-1243. Moors, E. J., 2012: Water Use of Forests in The Netherlands. PhD-thesis, Vrije Universiteit Amsterdam. Novick, K., and R. Phillips, 1999-2014: FLUXNET2015 US-MMS Morgan Monroe State Forest.

Pilegaard, K., A. Ibrom, M. S. Courtney, P. Hummelshoj, and N. O. Jensen, 2011: Increasing net CO2 uptake by a Danish beech forest during the period from 1996 to 2009. Agricultural and Forest Meteorology, 151, 934-946. Prescher, A. K., T. Grunwald, and C. Bernhofer, 2010: Land use regulates carbon budgets in eastern Germany: From NEE to NBP. Agricultural and Forest Meteorology, 150, 1016-1025.

Suni, T., and Coauthors, 2003: Long-term measurements of surface fluxes above a Scots pine forest in Hyytiälä, southern Finland, 1996-2001. Boreal Environment Research, 8, 287-301.

Suyker, A., 2001-2013a: FLUXNET2015 US-Ne3 Mead - rainfed maize-soybean rotation site.

Suyker, A., 2001-2013b: FLUXNET2015 US-Ne2 Mead - irrigated maize-soybean rotation site.

Suyker, A., 2001-2013c: FLUXNET2015 US-Ne1 Mead - irrigated continuous maize site. 
Wohlfahrt, G., A. Hammerle, A. Haslwanter, M. Bahn, U. Tappeiner, and A. Cernusca, 2008: Seasonal and interannual variability of the net ecosystem $\mathrm{CO} 2$ exchange of a temperate mountain grassland: effects of climate and management. Journal of Geophysical Research: Atmospheres 113, D08110.

Zielis, S., S. Etzold, R. Zweifel, W. Eugster, M. Haeni, and N. Buchmann, 2014: NEP of a Swiss subalpine forest is significantly driven not only by current but also by previous year's weather. Biogeosciences, 11, 1627-1635. 